\title{
Recreational Value of Vembanad Lake in Kerala Using Individual Travel Cost Method
}

\author{
V. Chandrasekar ${ }^{1 *}$, S. Murali Gopal ${ }^{2}$, A. Vidhyavathi ${ }^{2}$, \\ C. Jayanthi ${ }^{3}$, R. Sathy ${ }^{4}$ and Nikita Gopal ${ }^{1}$ \\ ${ }^{1}$ ICAR - Central Institute of Fisheries Technology, Cochin 682029, India \\ ${ }^{2}$ Department of Agricultural Economics, (CARDS), TNAU -Coimbatore, India \\ ${ }^{3}$ Dept of Agronomy, TNAU, Coimbatore - 641003, India \\ ${ }^{4}$ Department of Physical Sciences and Information Technology \\ AEC \& RI, TNAU - Coimbatore 641003, India \\ *Corresponding author
}

\section{Keywords}

Recreational value, Estuarine, Back water and travel cost

Article Info

Accepted:

21 May 2020

Available Online:

10 June 2020

\section{A B S T R A C T}

The Vembanadlake is the longest lake in India and also the largest wetland ecosystem in Kerala recognized as a Ramsarwetland site. The lake meanders through three districts of the state, Alappuzha, Ernakulum and Kottayam. It has been a source of livelihood to the population living alongside the wetland ecosystem. The economic activity carried in and around the backwater includes fishing, shrimp farming, clam picking, rice cultivation, duck rearing and livelihoods related to recreation like etc. Backwater tourism is a major revenue generation activity for the community by means of house boats, motor boats, shikara boat, speed boat etc. Around 1480 boats were operational in the Vembanadlake which are registered under the Department of Ports, Government of Kerala. The increase in boats is due to increase in the arrival of both foreign and domestic tourists, the increase of which over the past decade has risen by $11.69 \%$ and $7.07 \%$ respectively. In the year 2018 , foreign and domestic tourists who visited the Vembanad in the three districts (Alappuzha, Ernakulum and Kottayam) was approximately 0.63 and 4.48 million respectively. This paper aimed at measuring the recreation benefits obtained by tourists visiting the Vembanadlake (and the wetland ecosystem) using travel cost approach. The model considers number of visit made by the individual per annum as the dependent variable is and several independent variables such as cost of travel, family income, age, family size, time spent and quality of the backwater. The analysis was carried out using trip generating function. The results reveal that, the total recreational value of Vembanad backwater was 363 billion INR. The potential value of the ecosystem necessitates sustainable management and conservation of the lake and the backwater ecosystem, which is being affected by increasing pollution as a result of, ironically, increasing tourist activities. 


\section{Introduction}

In Kerala there are large number of perennial or temporary lakes which are locally also called as backwater Kayal. Kerala is famous for its backwater s which plays a vital role in sustaining the livelihood of local communities living in around the water bodies. During the past two decades there has been consistent increase in the number of tourists visiting Kerala, especially to visit the backwaters.

The Vembanadkol wetland covers about $1515.5 \quad$ sq. $\quad \mathrm{km} \quad$ (http://wiienvis.nic.in/ Database/ramsar wetland_sites_8224.aspx) and is a major back water tourist destination. It is famous for its biological diversity and provides various ecosystem services to the local communities. It supports fishing activities with its rich fish and shell fish resources and also has along its banks Chinese dip nets. Traditional aquaculture, brackish water agriculture (paddy field) are also carried out. Other traditional industries like coir making are also livelihood options for the people living in these areas. There are mangroves and bird sanctuaries and these are the activities that support the livelihood needs of the local population. Apart from these, tourism is growing sector in Kerala and backwater tourism is considered as one of the most popular forms which attracts investors in in houseboats, shikaras, passenger boats, speed boats with various packages etc. as also resorts, Ayurvedic centers, hotels, home-stay, restaurants, shops, travel agents, tour operators, taxi services etc. providing varied employment opportunities. Backwater tourism in Kerala attracts tourists from all over the world. The total number of tourists who arrived in the three districts (Alappuzha, Ernakulum and Kottayam) for visiting Vembanad backwaters was about 0.63 million foreign and 4.48 million domestic tourists (Kerala Tourist Statistics report, 2018), which shows about $11.69 \& 7.07 \%$ increase from its previous year. The increase in number of tourists between 2010 and 2018 has been from 2.82 to 5.11 million, with tourism earnings of 13.62 billion INR in the year 2018 in the three district alone (Kerala Department of Tourism, 2018), clearly indicating the immense potential from backwater tourism.

On the flip side, increasing tourism leads to increase in the number of house boat operations, resorts and other infrastructure development in around the Vembanad backwater which has been affected due pollution generated in the form of solid waste, oil leakage from house boat engines etc. Which are causing damage to the environment and ecosystem of the backwater. This in turn affects other activities such as fishing, clam harvesting an agriculture. This has also led to a shift in employment of the tourism sector.

In this study, recreation benefits obtained from the Vembanad backwater ecosystem was estimated using the Travel Cost Model (TCM). The TCM as a revealed preference method which is derived from the theory of consumer preferences and is measured by estimating the willingness-to-pay for the recreational benefits demanded, but not allocated, through market (Khan, 2006). Further, the perception of the quality of the backwater among the tourists and also their measure of happiness have been taken into consideration for number of visit to the site. This technique has been found to be useful in understanding the benefits of the ecosystem thus enabling the management of human intervention in an environmental sustainable manner (Paul et al., 2014; Varkey et al., 2016) which can be applied in other developing nations where there is risk to the natural capital. The quantification of recreational value as also study the visitors' perception about backwater quality will be highly useful for understanding the benefits of 
estuary ecosystem. This will helpful for managing the impacts of human activities as there is growing concern on environmental impacts of backwater tourism.

\section{Materials and Methods}

The recreation site selected for this study was Vembanadlake (backwater) which is situated in the central part of the Kerala spread acrossthree districts, namely Ernakulum (North), Alappuzha (West and South) and Kottayam (East). Vembanadlake and wetland is located between Lat. 9 $30^{\prime} 46^{\prime \prime}-10^{\circ} 11^{\prime} 11^{\prime \prime}$ $\mathrm{N}$ and Long. $76^{\circ} 09^{\prime} 48^{\prime \prime}-76^{\circ} 25^{\prime} 45^{\prime \prime} \mathrm{E}$ which is running parallel to the west coast of central part of Kerala.It is the longest coastal wetland water spread area with about $1512.50 \mathrm{Sq} \mathrm{Km}$. It is also the largest lagoon - backwater, humid tropical wetland ecosystem on the South West coast of India, designated as Ramsar site no.1214 during the year 2002 by the UNESCO.

\section{Data collection}

The primary survey was conducted during 2018-19 and data was collected using a wellstructured questionnaire directly from domestic tourists arriving from different parts of India for recreational purpose to Vembanad backwater. The sample respondents (tourists) at various spots were randomly selected in such a way that total sample size was 120 respondents. Individual Travel Cost Method (ITCM) has been used to measure the individual willingness-to-pay for the recreation site based on visiting rate to Vembanad backwater. Specifically the domestic tourist on single day visit to the Vembanad backwater was selected and expenditure incurred for air, road, water transport to make visit around recreational site was taken for study. The interview schedule consisted of two parts; one which sought respondent profiles such as age, marital status, education, income, place of residence and occupation and other basic information; and the second to measure the recreational behaviour of the visitors, which included questions on the number of visits, time spent, travel expenditure, mode of transportation and backwater qualitative aspects like ranking of both backwater quality and their overall satisfaction of the backwater trip.

\section{Tools and techniques}

Recreation benefits obtained from the Vembanad backwater ecosystem were estimated using the Individual Travel Cost Model (TCM). It is a revealed preference method which is derived from the theory of consumer preferences and is measured by estimating the willingness-to-pay for the recreational demanded destination. It is used to estimate economic use values associated with ecosystems or sites that are used for recreation. In the TCM, the environmental quality and demand for the site assume weak complementarity between them and measure how the environmental quality of the good (in this case Vembanadlake) affects the frequency of the visit by the people. It was assumed that the individuals utility depends on the total time spent at the site, the quality of the site and the quantity of private good other than travel consumed (Turpie and Joubert, 2001; Turpie et al., 2001; Bockstael, 1995; Willis and Garrod, 1991 and Clawson and Knetch, 1966). The time spent on the site can be represented by the number of visits.

The recreational use value of the Vembanad backwater was estimated using Individual travel cost method. In this model, dependent variable is considered as number of visit made by the individual per annum and the independent variable such as cost of travel, family income, age, family size, time spent and quality of backwater. The analysis was 
carried using trip generating function with count data poisson model (Hellerstein, 1991).

Here the Individual Travel Cost of single site model was used to describe the demand for recreation of a person during a year. The quantity demanded is the number of visits, price is the cost per visit and other variables are age of the respondent, income, experience, availability of substitute sites which may affect the number of visits to the site etc. The functional form is as given below:
$\mathrm{V}=\mathrm{f}\left(\mathrm{tc}_{\mathrm{v}}, \mathrm{tc}_{\mathrm{s}}, \mathrm{y}, \mathrm{z}\right)$

Where,

$\mathrm{V}=$ number of visits during a season

$\mathrm{tc}_{\mathrm{v}}=$ cost of a visit

$\mathrm{tc}_{\mathrm{s}}=$ price of trip to substitute site ' $\mathrm{s}$ ' (expect a positive correlation)

$\mathrm{z}=$ vector of socio-demographic characteristics of the respondent (age, gender, marital status, experience, etc.)

\section{Description of variable}

\begin{tabular}{|c|c|c|c|}
\hline S.No & Variable & Description & Unit \\
\hline 1 & Age & 21-30, 31-40, 41-50, 51-60, Above 60 & No. of Years \\
\hline 2 & Income & $\begin{array}{l}\text { Income groups: } 0-15000,15001-30000,30001- \\
45000,45001-60000,60001-75000, \text { Above } \\
75001\end{array}$ & Rupees \\
\hline 3 & Family size & Open ended question & Number \\
\hline 4 & Time spent & Total hours spend at the Vembanad backwater & Hours \\
\hline 5 & $\begin{array}{l}\text { Mode of } \\
\text { transport }\end{array}$ & $\begin{array}{l}\text { Owned vehicle, Hired vehicle and Public } \\
\text { transport }\end{array}$ & Number \\
\hline 6 & Cost of travel & Total cost from home to Vembanad backwater. & Rupees \\
\hline 7 & $\begin{array}{l}\text { Backwater } \\
\text { quality }\end{array}$ & Very poor, poor, fair, good and excellent & Number \\
\hline
\end{tabular}

\begin{tabular}{|c|c|}
\hline \multicolumn{2}{|c|}{ The empirical model } \\
\hline \multicolumn{2}{|c|}{$\begin{array}{l}\ln V=\alpha+\beta_{1} \text { TRVLCO }+\beta_{2} H H I+\beta_{3} F S I Z E+ \\
\beta_{4} T I M E S P+\beta_{5} M O T+\beta_{6} B W Q L T Y+\varepsilon,\end{array}$} \\
\hline $\begin{array}{l}\text { Where, } \\
V\end{array}$ & $=\quad$ Number of visits made by \\
\hline \multirow{2}{*}{\multicolumn{2}{|c|}{$\begin{array}{l}\text { individual per year } \\
\text { TRVLCO }=\text { Individual total cost of } \\
\text { visiting the site (Rs.) }\end{array}$}} \\
\hline & \\
\hline $\begin{array}{l}\text { HHI }= \\
\text { (Month) }\end{array}$ & Income of the household (Rs. \\
\hline$A G E$ & $=$ Age of the respondent \\
\hline FSIZE & $=$ Family size \\
\hline
\end{tabular}

$\begin{array}{ll}\text { TIMESP } & =\text { Time spend } \\ \text { MOT } & =\text { Mode of transport } \\ \text { BWQLTY } & =\text { Backwater quality } \\ \varepsilon & =\text { Error term }\end{array}$

Finally the Individual Consumer Surplus (ICS) of the recreational site was estimated with the help of integrating generated demand curve (between the number of visit made by the individuals per annum and the cost incurred to made that visits). Individual Consumer Surplus can be calculated by using the following formula (Damigos and Kaliampakos, 2001, Willis, 1991) 
$\mathrm{CS}=-1 / \beta_{\mathrm{ij}}$

Where,

CS - Consumer Surplus per person per trip $\beta_{\mathrm{ij}}$ - Coefficient of travel cost.

The total annual consumer surplus obtained from the recreation site can be calculated by multiplying the ICS with the number of visits made in a year (Mohammed El-Bekkay et al., 2013). The total recreational value of theVembanad backwaterwascalculated using the formula,

$V_{R}=C S^{*} V_{n}$

Where,

$V_{R}=$ Value of recreational services (Rs. per annum)

$C S=$ Consumer surplus per visitor (Rs.)

$V_{n}=$ Number of visitors per annum

\section{Multinomial logistic regression model}

The multinomial logistic regression model was used to assess happiness among visitors in Vembanad backwater. In this model "Somewhat happy" is taken as the baseline category for group level comparison, i.e., the model compares probability level of being 'very happy' and 'happy' compared to that of 'some-what happy' ( Hancock, 2013). The fitted regression model is given below:

$Y_{i}=\operatorname{In}\left(P_{j} / P_{1}\right)=\beta_{0}+\beta_{1} X_{1}+\beta_{2} X_{2}+\beta_{3} X_{3}$

$+\beta_{4} X_{4}+\beta_{5} X_{5}+\beta_{6} X_{6}+e_{i}$

Where,

$\mathrm{Y}_{\mathrm{i}}=$ Level of happiness (Very Happy; Happy:

Some What Happy)

$\mathrm{X}_{1}=$ Age of household

$\mathrm{X}_{2}=$ Income of household (Rs)

$\mathrm{X}_{3}=$ Quality of the Vembanad backwater (ranking)

$\mathrm{X}_{4}=$ Mode of Transport
$\mathrm{X}_{5}=$ Travel cost $(\mathrm{Rs})$

$\mathrm{X}_{6}=$ No of visits

\section{Results and Discussion}

The Vembanadlake and wetland is situated in Kerala and is located in three districts namely Ernakulum, Alappuzha and Kottayam. The number tourists (both foreign and domestic) who arrived in these three districts between 2010 and 2018 (Kerala Tourism Department, 2018 ) is presented in Figure 2. Out of the total tourists, nearly $87 \%$ are domestic tourists and the remaining $13 \%$ from other countries. Compound growth rate estimated for the total tourist arrived over the period from 2010 to 2018 in the three districts showed that there was 7.5 \%increase in tourist arrival per annum. The main reason being the unique wetland ecosystems of Vembanad lake which is a major backwater tourist destination with tourists mainly going for boating and appreciating the aesthetic beauty of the land and water bodies, having a taste of the traditional local culture and its biodiversity (Vincy et al., 2012). This also indicates that there was a rapid growth in the backwater tourism, which was bound to have an impact on the water quality which in turn would reduce the aesthetic value of the estuary and affect recreational visitation, which is crucial for the tourism revenue generation(Abraham, 2015; Thimm, 2017).

The descriptive analysis from the sociodemographic characteristics of the respondents is given in the Table 1. This study found that about $67.5 \%$ of the tourists were from urban areas. About $63.3 \%$ of respondents were married and $36.7 \%$ were single.

Figure 3 shows the distribution of the respondents based on their age and income group. Normally age is an important factor which determines the recreational activities. 
Respondents up to 30 years were more frequency of visiting the Vembanad backwater $(41.7 \%)$. Respondents who were 51 years and above were only about $5 \%$. Overall about $87(72 \%)$ out of 120 visitors were less than 41 years of age. The result clearly shows that young people travel long distances to spend their leisure time rather than older people. The next essential variable to be studied is income of the respondents and it is observed that $35.8 \%$ of respondents fall in the income class of INR 20001-50000 per month. The middle income group varies from INR $50001-100000$ per month of about $27 \%$ and $13 \%$ of high income group respondents fall under the income category of above INR 100000 per month. Overall, about $79 \%$ of the households fall in the income range of INR 10000 to 75000 per month.

The mode of transportation is shown in Table 3 and it is found that majority of the respondents were coming in their own vehicles $(38.33 \%)$, since hiring private vehicles is expensive. About $29 \%$ respondents depend on public mode of transportation and $32.5 \%$ on private vehicles to reach the recreation site.

The respondents were asked to express their opinion about the quality of the Vembanad backwater on a 5 point scale (very poor, poor, fair, good and excellent). The opinion of the respondents' recreational benefits is given in the Table 4. It is found that $32.5 \%$ of the respondents expressed good opinion about quality of Vembanad backwater and $45.8 \%$ of respondents felt from range of fair to very poor in the quality of backwater. This is an indicator that the lake has been affected by various forms of pollution. Studies have pointed out that there was decline in the backwater quality due to regular discharge of domestic and municipal sewage waste, apart from that discharge of waste from fish and shrimp processing units, oil spillage, solid and liquid wastage from houseboat, coir retting, liquid insecticide, weedicides, fungicides and chemical fertilizers discharged from the surrounding paddy field area reach in to this Vembanad backwater (Safoora et al., 2014, Sitaram, 2014; Balachandran et al., 2005). About $21.7 \%$ of respondents said that the quality was excellent. From our analysis it is inferred that substantial percentage of the visitors felt that the quality of the backwater is good compared to their places. This perception might be a reason for increase in tourist footfalls to this area. However there has been exploitation in terms of encroachment and reclamation of estuarine ecosystem by the other means of expansion such as harbor development, agriculture, coir industries and aquaculture (Sitaram, 2014). Apart from that, the waste generated from the treated and untreated sewage, deposits from the surrounding settlement as well as houseboats, pollution from the tourism port are also major issues (Mathew et al., 2017;) and may have an impact on tourism in future.

The total coliform Bacteria are $30 \%$ higher in Houseboat jetty than in the remaining area.

It may compromise their future ability to sustain healthy ecosystems and the provision of ES. Such deterioration comes in the form of water quality reduction from pollution, eutrophication and mining activities, but also as encroachment and reclamation of lake area (Kokkal et al., 2007; WISA, 2013).

Multiple regression analysis was employed in order to measure the individual consumer surplus, which is mainly used to determine important factors contributing to the visit made by the individual in a year. The recreational use value of the Vembanad backwater estimated using Individual Travel Cost Method is given in the table 5. The $\mathrm{R}$ square variable was 0.51 , i.e., $51 \%$ of the dependent variable is being explained by the 
independent variable. Based on these variable construct a demand function for the Vembanad backwater was developed as follows:

$\ln V=0.5518-0.00001_{(\text {TRVLCO })}+0.00002_{(H H I)^{-}}$ $0.0045_{(A G E)}-0.0499_{(F S I Z E)}-0.0096$

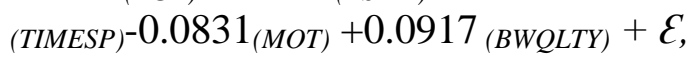

The regression results revealed that, the negative coefficient of the travel cost shows that travel cost incurred by an individual is inversely related to number of visits to the backwater per annum (Anoop et al., 200; Vijayan and Job, 2015). The negative sign indicates that higher the amount spent on travel by visitors to reach the Vembanad backwater, lesser is the frequency of their visit, i.e., people living nearer to the Vembanad backwater made frequent visits and those living far away from the backwater made fewer trips. Another variable which positively influences the visitation rates was monthly income of the respondents. This indicates that higher level of family income increases the backwater visitation rates, with surplus incomes for recreational activities. Age and family size shows significant and opposite relationship between the annual numbers of visits, indicating that with increase in family size and age visits to recreational sites was less. Another crucially important variable is the respondent perception about the quality of the backwater, which shows significant positive relationship with number of visits. This indicates that improvement in the quality of the Vembanad backwater will increase the number of visitors per annum in the recreational site. It is generally observed that pollution is more obvious during the dry season when the tourism demand is also high coinciding with the domestic holiday season and the assimilative capacity tends to be less (Paul et al., 2014). The decline in the quality of the Vembanadback waters was due to continuous increase in the number of houseboats, resorts and hotels to meet the increasing demand, without considering the supporting capacity of the natural ecosystem with in which they reside it (WISA, 2013; Paul et al., 2014; and WISA \& CWRDM, 2017).

\section{Estimating of consumer surplus}

With help of the above estimated demand curve, individual consumer surplus were calculated which is INR 81039.61 per person (Table 6). The total consumer surplus has been arrived by multiplying with the total number of visitors at the site during the year (as per the Kerala Tourism Statistics, 2018) and has been calculated at INR 4.48 million. Hence the total consumer surplus was estimated at Rs.363.32 billion, which is the annual recreational use value of the Vembanad backwater.

A multinomial logit model (Hencock, 2013) was used to measure the variables influencing happiness among the visitors to the Vembanad backwater. In the multinomial logit regression, the base option in the categorical variable is used for baseline comparison groups. In the iteration the log quickly converged and overall the model is significantly fit with likelihood ratio chisquare value of 87.2. Table 7 shown that travel cost is not significant, but the coefficient of backwater quality is positive and also highly significant in both 'very happy' and 'happy' visitors, which indicates that quality of the Vembanad backwater decided their happiness rather than the cost incurred for the for visiting the recreational site. In addition to that, visitor's income and their mode of transportation also significantly influenced their level of happiness. 
Table.1 Socio-demographic details of respondents visiting at Vembanad backwater

\begin{tabular}{|l|l|c|c|}
\hline \multicolumn{2}{|c|}{ Particular } & Frequency & Percentage \\
\hline \multirow{4}{*}{ Location } & Rural & 39 & 32.50 \\
\cline { 2 - 4 } & Urban & 81 & 67.50 \\
\cline { 2 - 4 } Gender & Total & $\mathbf{1 2 0}$ & $\mathbf{1 0 0}$ \\
\cline { 2 - 4 } & Male & 64 & 53.33 \\
\cline { 2 - 4 } & Female & 56 & 46.67 \\
\cline { 2 - 4 } Marital & Total & $\mathbf{1 2 0}$ & $\mathbf{1 0 0}$ \\
\hline \multirow{2}{*}{\begin{tabular}{l} 
Status \\
\multirow{2}{*}{}
\end{tabular}} & Uarried & 76 & 63.33 \\
\hline & Total & 44 & 36.67 \\
\cline { 2 - 4 } & Totried & $\mathbf{1 2 0}$ & $\mathbf{1 0 0}$ \\
\hline
\end{tabular}

Table.3 Different mode of travel details about visitors

\begin{tabular}{|l|c|c|}
\hline Mode of travel & Frequency & Percentage \\
\hline Own vehicle & 46 & $\mathbf{3 8 . 3 3}$ \\
\hline Hired vehicle & 39 & $\mathbf{3 2 . 5 0}$ \\
\hline $\begin{array}{l}\text { Public } \\
\text { transport }\end{array}$ & 35 & $\mathbf{2 9 . 1 7}$ \\
\hline Total & & $\mathbf{1 0 0 . 0 0}$ \\
\hline
\end{tabular}

Table.4 Visitors' perceptions related to the quality of Vembanad backwater

\begin{tabular}{|l|c|c|}
\hline Backwater quality & Frequency & Percentage \\
\hline Very poor & 2 & 1.67 \\
\hline Poor & 20 & 16.67 \\
\hline Fair & 33 & 27.50 \\
\hline Good & 39 & 32.50 \\
\hline Excellent & 26 & 21.67 \\
\hline \multicolumn{1}{|c|}{ Total } & $\mathbf{1 2 0}$ & $\mathbf{1 0 0}$ \\
\hline \multicolumn{2}{|c|}{} \\
\hline
\end{tabular}

Table.5 Parameter estimates of trip generating function

\begin{tabular}{|l|l|r|r|}
\hline \multicolumn{1}{|c|}{ Variable } & \multicolumn{1}{c|}{ Coefficient } & & \multicolumn{1}{c|}{ P value } \\
\hline Constant & $0.5518^{* * *}$ & 0.1694 & 0.0014 \\
\hline TRVLCO & $-0.00001^{* * *}$ & $3.05 \mathrm{e}-06$ & 0.0000 \\
\hline HHI & $0.00002^{* * *}$ & $6.22 \mathrm{e}-07$ & 0.0008 \\
\hline AGE & $-0.0045^{* *}$ & 0.0021 & 0.0278 \\
\hline FSIZE & $-0.0499 *$ & 0.0233 & 0.0343 \\
\hline TIMESP & -0.0096 & 0.0075 & 0.2019 \\
\hline MOT & $-0.0831^{* * *}$ & 0.0252 & 0.0052 \\
\hline BWQLTY & $0.0917 * *$ & 0.0292 & 0.0004 \\
\hline R $^{\mathbf{2}}$ & & $\mathbf{0 . 5 1}$ \\
\hline
\end{tabular}

Note: ***,** and * implies significance at $1 \%, 5 \%$ and $10 \%$ respectively. (Standard errors are presented in Parenthesis) 
Table.6 Recreational value of Vembanad backwater

\begin{tabular}{|l|c|}
\hline \multicolumn{1}{|c|}{ Particulars } & Value \\
\hline Consumer surplus per visit (INR) & 81039.61 \\
\hline No. of visitors per annum (Nos) & 4483200 \\
\hline Total consumer surplus (INR) & 363316779552 \\
\hline Recreational value per annum (billion INR) & 363.32 \\
\hline
\end{tabular}

Table.7 Happiness among visitors in the Vembanad backwater

\begin{tabular}{|c|c|c|c|c|}
\hline & Coefficient & Std. Error & $\mathbf{z}$ & p-value \\
\hline \multicolumn{5}{|c|}{ Very happy Vs Somewhat happy } \\
\hline Constant & $-11.0133 * *$ & 4.4576 & -2.4700 & 0.0130 \\
\hline Age & -0.0250 & 0.0420 & -0.6000 & 0.5520 \\
\hline Income & $0.0001 * *$ & 0.0000 & 2.5200 & 0.0120 \\
\hline Quality of backwater & $5.3840 * * *$ & 1.5523 & 3.4700 & 0.0010 \\
\hline Travel cost & 0.9212 & 0.8145 & 1.1300 & 0.2580 \\
\hline Mode of transport & $-0.0004 * * *$ & 0.0001 & -3.2600 & 0.0010 \\
\hline No of visit & 2.2369 & 1.3919 & 1.6100 & 0.1080 \\
\hline \multicolumn{5}{|c|}{ Happy Vs Somewhat happy } \\
\hline Constant & -6.0441 & 4.2590 & -1.4200 & 0.1560 \\
\hline Age & -0.0484 & 0.0400 & -1.2100 & 0.2260 \\
\hline Income & $0.0001 * *$ & 0.0000 & 2.5600 & 0.0100 \\
\hline Quality of backwater & $4.5797 * * *$ & 1.5354 & 2.9800 & 0.0030 \\
\hline Travel cost & 0.9218 & 0.7943 & 1.1600 & 0.2460 \\
\hline Mode of transport & $-0.0004 * * *$ & 0.0001 & -3.2800 & 0.0010 \\
\hline No of visit & 1.0046 & 1.3615 & 0.7400 & 0.4610 \\
\hline
\end{tabular}

Note: $* * * 1 \%, * * 5 \% \& * 10 \%$ level of Significance

Figure.1 Map showing the location of Vembanadlake and wetland, Kerala, India

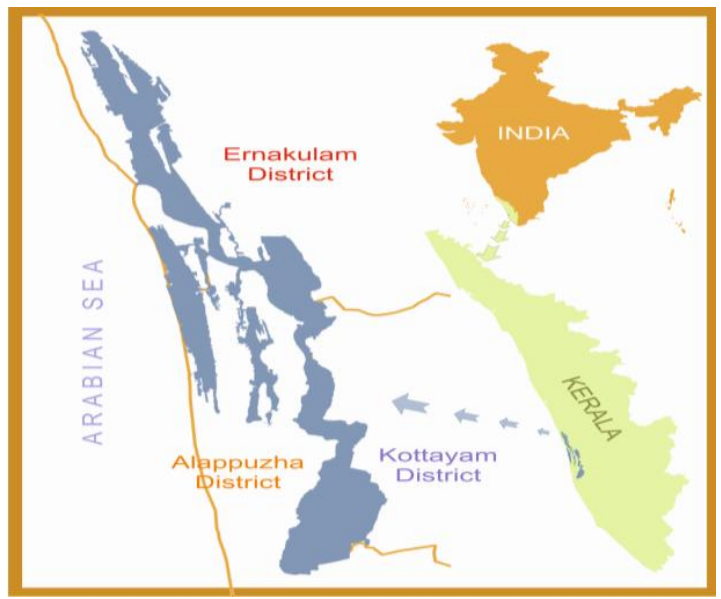


Figure.2 Total no of tourist arrived in three district (Ernakulum, Alappuzha and Kottayam) of Kerala during the year 2010 to 2018

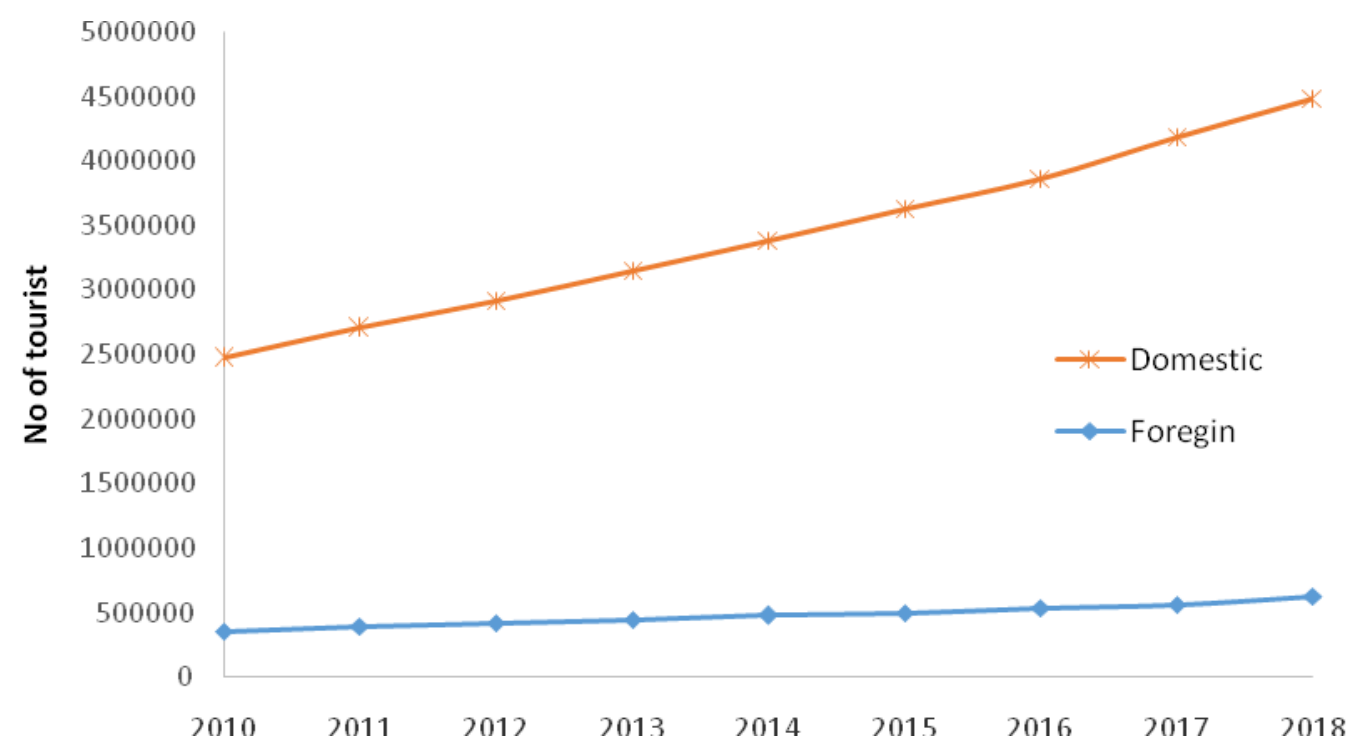

Figure.3 Age and income group distribution of tourist respondents

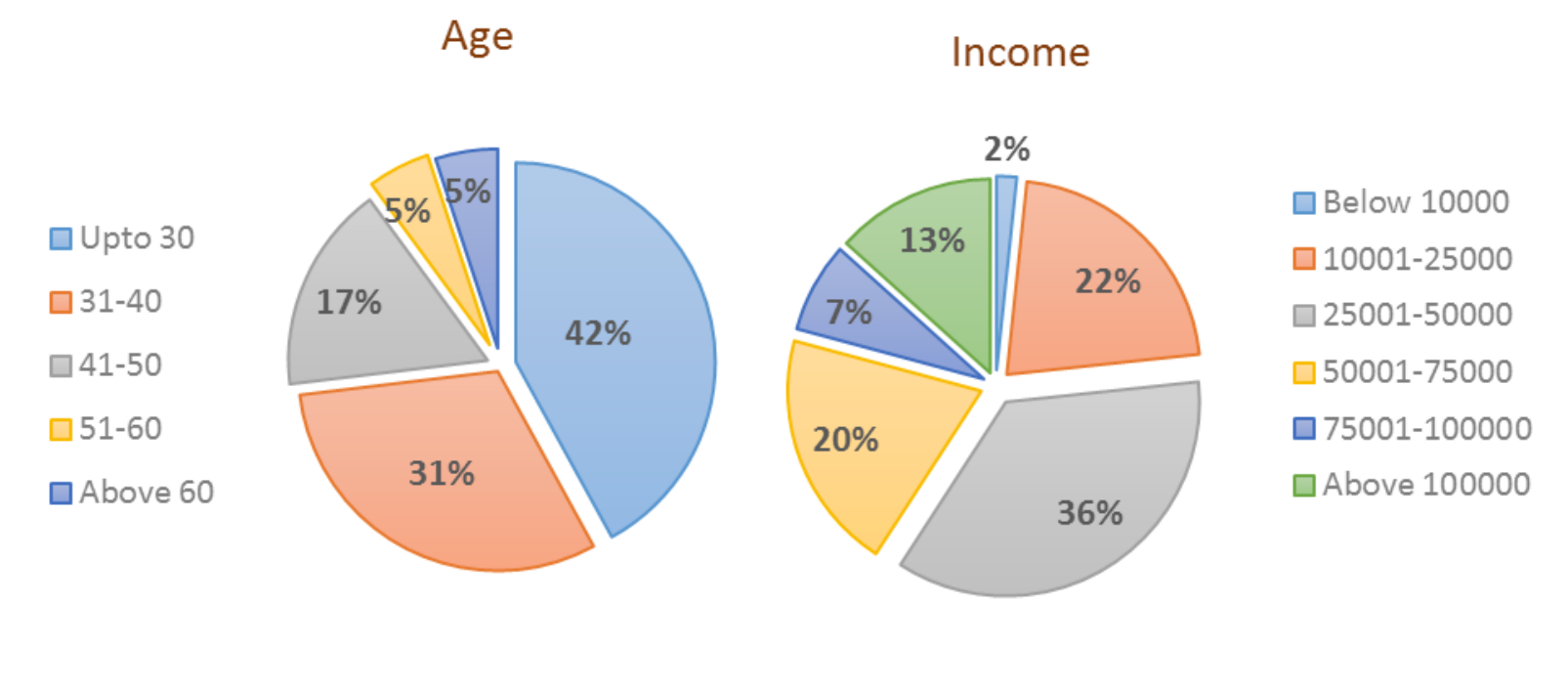

In conclusion, the results of the above study clearly indicate that visits of domestic tourists to the Vembanad backwater is influenced by their income and quality of the backwater. Travel cost, age, family size and mode of transportation have negative impacts and improvements in transport infrastructure and reduction in costs can improve visitations to the Vembanad backwaters and increase backwater tourism, which has a recreational use value of about INR 363 billion and individual consumer surplus of INR.81039. Over the coming years there will be increase in number of tourists and consequent to this (and other factors) increase in the pollution which if done without considering the supporting capacity of the natural ecosystem will have negative consequences. If it 
continues in future, deterioration of water quality will negatively impact on number of tourist visitation rate, which will not only affect the revenue generation from the tourism industry, but also affect the livelihoods of the different people dependent on it. The backwater is a common property resources and various stakeholders such as boat owners, resort, hotels, homestay etc. must take responsibility and come forward to improve the backwater quality. Similarly the percentage of state government fund allocated to protect the wetland water bodies insufficient, and importance on spending funds on setting up of stalls, arranging exhibitions in foreign countries and organizing tourism melas etc. will only serve limited purposes. Other government bodies like the Pollution Control Board also need to take adequate responsibility to protect the water bodies from all sorts of pollution. It is important to manage the impact of human activities so that the backwater tourism can be sustained and will continue to provide economic benefits to the people dependent on it as well as recreational benefits to tourists visiting. .

\section{References}

Anoop, P., and Suryaprakash, S. (2008). Estimating the option value of Ashtamudi Estuary in South India: A contingent valuation approach. In International Congress of European Association of Agricultural Economists, Ghent, Belgium.

Abraham, S. (2015). The relevance of wetland conservation in Kerala. International Journal of Fauna and Biological Studies, 2(3), 1-5.

Balachandran, K. K., Laluraj, C. M., Nair, M., Joseph, T., Sheeba, P., and Venugopal, P. (2005). Heavy metal accumulation in a flow restricted, tropical estuary. Estuarine, Coastal and Shelf Science,
65, 361-370.Clawson M, Knetsch (1966) J. Economics of Outdoor Recreation, Washington, DC. Resource of the Future.

Damigos D, Kaliampakos D. (2001) Economic Valuation of Mined Land Reclamation: An Application of Individual Travel Cost Method in Greece, International Conference of Mine Producing, Geology and Environment Protection, VarnaBulgaria;

Hellerstein, D.M., (1991) Using count data models in Travel cost analysis with aggregate data, American Journal of Agricultural Economics, 73: 860- 867.

Hencock, E. K. (2013) Assessing Happiness: How Economic factors measure up. The Ames Library publication.

Khan H. (2006) Willingness to Pay for Margalla Hills National Park: Evidence from the Travel Cost Method, The Lahore Journal of Economics. 11(2): 43-70.

Mathew, R., and Swain, S. K. (2017). Backwater tourism: RT initiatives and socio-environmentaldynamics. SCMS Journal of Indian Management, 14(2).

Mohammed El-Bekkay, Abedellatif Moukrim, Faical Benchakroun (2013). An economic assessment of the Ramsar site of Massa with travel cost and contingent valuation methods. African Journal of Environmental Science and Technology. 7(6):441-447.

Paul, K., Alias, B., and Varghese, S. (2014). Spatial distribution of non-point source pollution in Vembanad Lake. International Journal of Innovative Research in Science and Engineering, 2(2), 1-6.

Sitaram, N. (2014). Impact of urbanisation on water quality parameters - a case study of Ashtamudi Lake, Kollam. International Journal of Research in Engineering and Technology, 3(6), 
140-147.

SafooraBeevi, K. H., and Devadas, V. (2014). Impact of tourism on Vembanadlake system in Alappuzha district. International Journal of Research, 1(5), $542-551$.

Thimm, T. (2017). The Kerala tourism model: An Indian state on the road to sustainable development. Sustainable Development, 25, 77-91.

Vijayan, A., Job, E., (2015) Recreational value of Vellayanilake in South India: a travel cost approach. Int. J. Sci. Res., 4 (11), 156-158.

Vincy, M. V., Rajan, B., and Kumar, A. P. (2012). Water quality assessment of a tropical wetland ecosystem with special reference to Backwater Tourism,
Kerala, South India. International Journal of Environmental Science, 1(5), $62-68$.

WISA (2013). Vembanad - Kol Wetlands an integrated management planning framework for conservation and wise use. Technical report submitted to the IUCN and MoEF New Delhi: Wetlands International-South Asia, New Delhi, India.

WISA, and CWRDM (2017). Ashtamudi estuary, Kerala - an integrated management plan. Technical report submitted to the directorate of environment and climate change. Environment Department, Government of Kerala.

\section{How to cite this article:}

Chandrasekar, V., S. Murali Gopal, A. Vidhyavathi, C. Jayanthi, R. Sathy and Nikita Gopal. 2020. Recreational Value of Vembanad Lake in Kerala Using Individual Travel Cost Method. Int.J.Curr.Microbiol.App.Sci. 9(06): 3280-3291. doi: https://doi.org/10.20546/ijcmas.2020.906.391 